(h) The Specialized Organizations, intergovernmental organizations established by multilateral agreements to discharge specific functions in their respective fields of action, such as women's affairs, agriculture, child welfare, Indian affairs, geography and history, and health.

Headquarters: 17th St. and Constitution Ave., NW, Washington, D.C., 20006-4499, USA.

Website: http://www.oas.org

Secretary-General: Luis Almagro (Uruguay).

\section{Pacific Alliance}

Origin and Aims. The Pacific Alliance was founded in June 2012 through the Pacific Alliance Framework Agreement. The group had informally come together with the signing of the Lima Declaration a year earlier.

Its principal aims are to encourage free trade and economic integration between member states, facilitate freedom of movement and pursue multilateral ties with other regions. A number of jointly-run embassies and consulates have been opened.

Organization. The Alliance holds regular summits attended by heads of member states. This is the leading decision-making body. There is also a Council of Ministers, comprising ministers of foreign affairs and foreign trade, as well as a High-Level Group made up of their deputy ministers.

Membership. In Feb. 2016 there were four members: Chile, Colombia, Mexico and Peru, with a combined GDP exceeding US $\$ 1.7$ trn. Costa Rica and Panama were in the process of joining as of Feb. 2016. Countries with observer status in Feb. 2016 were: Australia, Austria, Belgium, Canada, China, Denmark, Dominican Republic, Ecuador, El Salvador, Finland, France, Georgia, Germany, Greece, Guatemala, Haiti, Honduras, Hungary, India, Indonesia, Israel, Italy, Japan, South Korea, Morocco, Netherlands, New Zealand, Paraguay, Poland, Portugal, Singapore, Spain, Sweden, Switzerland, Thailand, Trinidad and Tobago, Turkey, UK, USA, Uruguay.

Website: http://alianzapacifico.net

President pro tempore: Ollanta Humala Tasso (Peru).

\section{Secretariat for Central American Economic Integration (SIECA)}

SIECA (Secretaría de Integración Económica Centroamericana) was created by the General Treaty on Central American Economic Integration in Dec. 1960. The General Treaty incorporates the Agreement on the Regime for Central American Integration Industries. In Oct. 1993 the Protocol to the General Treaty on Central Economic Integration, known as the Guatemala Protocol, was signed.

Members. Costa Rica, El Salvador, Guatemala, Honduras, Nicaragua, Panama.

Official language: Spanish.

Headquarters: 4a Avenida 10-25, Zona 14, Ciudad de

Guatemala, Guatemala.

Website: http://www.sieca.int

Secretary-General: Carmen Gisela Vergara (Panama).

\section{Southern Common Market (MERCOSUR)}

Founded in March 1991 by the Treaty of Asunción between Argentina, Brazil, Paraguay and Uruguay, MERCOSUR committed the signatories to the progressive reduction of tariffs culminating in the formation of a common market on 1 Jan. 1995. This duly came into effect as a free trade zone affecting $90 \%$ of commodities. A common external tariff averaging $14 \%$ applies to $80 \%$ of trade with countries outside MERCOSUR. Details were agreed at foreign minister level by the Protocol of Ouro Preto signed on 17 Dec. 1994.

In 1996 Chile negotiated a free trade agreement with MERCOSUR which came into effect on 1 Oct. Subsequently Bolivia, Chile, Colombia, Ecuador, Guyana, Peru and Suriname have all been granted associate member status. Bolivia began the accession process to full membership in 2012. Mexico and New Zealand have observer status. Venezuela, which had associate membership between 2004 and 2006, became the fifth member of MERCOSUR in July 2006, although it was not going to have full voting rights until all the other full members had ratified its entry into the organization. Paraguay was the only country still to approve Venezuela's full membership, but it was suspended from MERCOSUR in June 2012 following the impeachment of its president, Fernando Lugo. With Paraguay suspended, Venezuela was then formally admitted in July 2012. Paraguay was readmitted in Aug. 2013 after the swearing-in ceremony of its new democratically-elected president, Horacio Cartes.

Organization. The member states' foreign ministers form a Council responsible for leading the integration process, the chairmanship of which rotates every six months. The permanent executive body is the Common Market Group of member states, which takes decisions by consensus. There is a Trade Commission and Joint Parliamentary Commission, an arbitration tribunal whose decisions are binding on member countries, and a secretariat in Montevideo.

Further to the treaty signed by 12 South American countries in May 2008, it is anticipated that MERCOSUR will gradually be integrated into the Union of South American Nations.

Headquarters: Dr Luis Piera 1992, Piso 1, 11200 Montevideo,

Uruguay.

Website (Spanish and Portuguese only):

http://www.mercosur.int

President pro tempore: Tabaré Vázquez (Uruguay).

\section{Union of South American Nations (UNASUR)}

History. Established in May 2008 in Brazil, it is anticipated that the Union of South American Nations will eventually supersede MERCOSUR and the Andean Community, creating an enlarged customs union with a single market, parliament, secretariat and central bank, based on the European Union structure. UNASUR is the successor body to the now defunct South American Community of Nations (CSN/SACN), founded in 2004. Despite initial problems, progress was made at UNASUR's fourth Summit in Nov. 2010 culminating in the 'Georgetown Declaration', with the attending heads of state and government and foreign ministers highlighting their commitment to working together to achieve a better South America. The Treaty establishing UNASUR became effective on 11 March 2011.

Organization. There is a permanent secretariat based in Quito, Ecuador. A proposed South American parliament is planned for 